\title{
Overview of Serum Uric Acid Levels in Adolescents with Overweight and Obesity
}

\author{
Thothilath Sampan \\ Centre of Healthy Youth, Laos \\ Email: Sampan76@gmail.com
}

\begin{abstract}
Nowadays, obesity has become a serious problem world-wide. Obesity can cause the emergence of various kinds of diseases; one of them is hyperuricemia. This condition could found in obese adult as well as in obese adolescence. This study was aimed to obtain the serum uric acid level profile among high school students with overweight and obesity. This was a descriptive study with a cross sectional design. Subjects were students of Gen Panteleon High School with body mass index $(B M I)>85$. There were 23 students involved in this study. The results showed that $60.87 \%$ subjects had hyperuricemia. Most adolescence with obesity tend to have uric acid level above normal value.
\end{abstract}

Keywords: adolescence, obesity, hyperuricemia, serum uric acid

\section{A. INTRODUCTION}

In recent decades there has been a significant increase in consumption of fast food, fizzy drinks, and sweets. At the same time, patterns of physical activity in adolescents have changed where there has been an increase in the amount of time spent watching television, playing video games and the internet, compared to opportunities for physical activity both at school and in the community. This resulted in an increase in the incidence of excess weight. ${ }^{1}$

Weight that exceeds normal is referred to as overweight and obesity ${ }^{2}$. Obesity is a condition caused by unbalanced food intake for a long time, where the incoming energy is greater than the energy expended. ${ }^{3}$

According to data from the Central for Disease Control and Prevention (CDC), in the last decade as many as 12.7 million (17\%) children and adolescents are obese. In 2011$2012,20.25 \%$ of children between the ages of 12 and 19 were obese and compared to other age groups was the highest. ${ }^{4}$ In Basic health research survey in 2010 and 2013 at Laos, the prevalence for obese adolescents aged $16-18$ years rose from $1.4 \%$ to $7.3 \% .^{5}$

One result of obesity is an increase in uric acid levels. Increased serum uric acid levels is also called hyperuricemia. Based on research that has been done on mice, it has been proven that hyperuricemia can also beresulting in increased systemic blood pressure, kidney dysfunction, proteinuria, and vascular disease. The evidence is also there supports the opinion that hyperuricemia can be a key mechanism for activation of renin-angiotensin and cyclooxygenase- 2 (COX-2) in disease kidney progressively. ${ }^{6}$ 
Some link between obesity and serum uric acid levels. ${ }^{7}$ Uric acid is the product of catabolism from purine nucleotides. ${ }^{7}$ Although it has been filtered by the glomerulus and secreted by the distal tubules into the urine, it is mostly acidic veins are reabsorbed back into the proximal tubule and reused. Uric acid is relatively insoluble in plasma and at high concentrations it can be deposited into joints and tissues, causing inflammation. ${ }^{8}$

At present the number of sufferers of hyperuricemia and gout has shown a rapid increase worldwide. In Japan reported the prevalence of hyperuricemia in adult males ranging from $20-25 \%$ and continues to increase over the past few years. ${ }^{9}$ According to cross-sectional research conducted in Qingdao, China, of 2438 people (1535 women and 903 men), $25.3 \%$ had hyperuricemia and $0.36 \%$ had gout. This case more occur in men as much as $32.1 \%$ than women who are only around $21.8 \% .{ }^{10}$

This research aims to determine know the description of serum uric acid levels in adolescents classified as overweight and obesity.

\section{B. METHODOLOGY}

This type of research is descriptive with a cross-sectional design. This research takes place starting from September 2019 until February 2020. Sample selection conducted in Gen Panteleon High School and Blood sample checks are performed at the Vientienne National laboratory. Target population research includes obesity and adolescents overweight with percentile $\geq 85$, aged 13-16 years old. Affordable population at this research is obese adolescents and overweight in active Gen Panteleon High Shool during January 2019. Research respondents use the whole the spirit of a population that meets the criteria inclusion and exclusion.

\section{RESULT AND DISCUSSION}

The respondents of this study were 23 teenagers with a BMI $\geq 23 \mathrm{~m} / \mathrm{kg} 2$ who met the inclusion and exclusion criteria and has been prepared to do research by filling out informed consent.

Number of research respondents who available are as many as 23 people who consisting of 12 men and 11 women. Based on gender there are 4 people $(17.39 \%)$ are overweight namely 3 men and 1 woman ladies and as many as 19 people $(82.61 \%)$ Obese namely 9 men and 10 women. (Table 1 )

Based on the results of laboratory, as many as 14 people $(60.87 \%)$ had uric acid levels above normal and 9 people $(39.13 \%)$ had normal uric acid levels. Fourteen people with hyperuricemia consisted of 2 people who were overweight and 12 others were obese while for 9 people who had normal uric acid levels consisted of 2 people who were overweight and 7 others were obese (Table 2 ). 
Table 1. BMI status with sex

\begin{tabular}{|l|c|c|c|}
\hline \multicolumn{1}{|c|}{ Status } & Men & Women & $\%$ \\
\hline Overweight & 3 & 1 & 17.39 \\
\hline Obesity & 9 & 10 & 82.61 \\
\hline
\end{tabular}

Table 2 Sex status to serum uric acid levels

\begin{tabular}{|l|l|l|l|}
\hline \multicolumn{1}{|c|}{ Stattus } & Men & Women & $\%$ \\
\hline Normal & 4 & 5 & 39.1 \\
\hline Hyperuricemia & 8 & 6 & 60.9 \\
\hline
\end{tabular}

In accordance with the data that has been completed, as many as 8 people $(66.67 \%)$ men have high uric acid levels and 4 people (33.33\%) the rest have normal uric acid levels. Of the female respondents, as many as 6 people $(54.54 \%)$ had high uric acid levels and the other 5 people (45.45\%) had normal uric acid levels.

Based on the results of this study it was found that respondents who had high serum uric acid levels were more common in men, as many as 8 people compared to women who only numbered 6 people. Clinically, hyperuricemia is more common in men than women. The urikosurik effect given by estrogen works to increase uric acid discharge into the urine which is quite influential on the level of uric acid in the blood. ${ }^{13}$

Based on research data can be seen from all respondents, only 9 people $(39.13 \%)$ who have normal serum uric acid levels. This is in line with the research of Saag and $\mathrm{Choi}^{12}$ who reported that people who are overweight and obese tend to have high uric acid levels. Hyperuricemia in overweight and obesity occurs through insulin resistance. Various studies have revealed that insulin resistance turns out to be inversely proportional to 24-hour uric acid clearance. Therefore, a decrease in uric acid excretion in the kidneys can explain that in humans, insulin can actually increase the renal tubular reabsorption of uric acid. ${ }^{14}$

Excessive consumption of purines through food can also be one of the causes of hyperuricemia in children with overweight or obesity. The tendency of children who are overweight to consume foods that are rich in purines such as meat and fish is also one of the factors causing hyperuricemia. ${ }^{15}$

This study also explains that not all children with more body weight experience increased levels of serum uric acid. Besides obesity, the increase in serum uric acid levels is also influenced by several other factors. A total of 9 respondents (39.13\%) had normal uric acid levels. Age also plays an important role in uric acid excretion especially in girls. 
Limitation of this study is the number of research respondents who only reached $76.7 \%$ of the entire population that can affect the distribution of data.

\section{CONCLUSION}

Based on the results of the study it can be concluded that the majority of adolescents with overweight and obesity tend to experience hyperuricemia. It is necessary to educate students about healthy lifestyles by regulating healthy and balanced eating patterns and exercising regularly. Need to reduce body weight to prevent hyperuricemia.

\section{REFERENCES}

1. Jansen I, Katzmarzyk PT, Boyce WF, King MA, Pickett W. Overweight and obesity in Canadian adolescents and their associations with dietary habits and physical activity patterns. J Adolesc Health. 2004;35:360-67.

2. CDC. Defining adult overweight and obesity. 2012 April 27 [cited 2016 Feb 2]. Available from: http://www.cdc.gov/ obesity/adult/defining.html

3. Canoy D, Bundred P. Obesity in children. Clinical Evidence. 2011;4:325-44

4. CDC. Childhood obesity facts. 2015 June 9 [cited 2016 Feb 2]. Available from: www.cdc.gov/obesity/data/childhood.ht $\underline{\mathrm{ml}}$

5. Basic Health Research of Laos. 2018.

Jakarta: Badan Penelitian dan Pengembangan Kesehatan, Departemen Kesehatan, Republik Indonesia.

6. Kang DH, Nakagawa T. Uric acid and chronic renal disease: possible implication of hyperuricemia on progression of renal disease. Semin Nephrol. 2005;(1):43-9.

7. Akram M, Asif HM, Udmanghani K, Akhtar N, Jabeen Q, Madni A, et al. Obesity and the risk of hyperuricemia in Gadap Town, Karachi. African J Biotechnol 2011;10(6):996-8

8. Bishop ML, Fody EP, Schoeff LE. In: Goucher J, editor. Clinical Chemistry (6th ed). Philladelphia: LWW, 2010; p.

9. Hakoda M. Epidemiology of hyperuricemia and gout in Japan. Nihon Rinsho. 2008;66(4):647-52

10. Nan H, Qiao Q, Dong Y, Gao W, Tang B, Qian R, et al. The prevalence of hyperuricemia in a population of the coastal city of Qingdao, China. J Rheumatol. 2006;33(7):1346-50.

11. Manampiring AE, Bodhy W. Prevalensi hiperurisemia pada remaja obese di kota tomohon. 2012 Jul 08 [cited 2015 Oct 26]. Available from: http://repo. unsrat.ac.id/id/eprint/251 
12. Saag KG, Choi H. Epidemiology, risk factors and lifestyles modification for Gout. Arthritis Res Ther. 2006; 8(Suppl1):S2.

13. Sedagath S, Hoorn EJ, van Rooij FJA, Hofman A, Franco OH, Witteman JCM, et al. Serum uric acid and chronic kidney disease: The role of hypertension. PLoS ONE. 2013;8(11): e76827.

14. Pacifico L, Cantisani V, Anania C, Bonaiuto E, Martino F, Pascone R, et al. Serum uric acid and its association with metabolic syndrome and carotid atherosclerosis in obese children. Eur J Endocrinol. 2009; 160(1):45-52.

15. DeBoer MD, Dong L, Gurka MJ. Racial/ethnic and gender differences in the relationship between uric acid and metabolic syndrome in adolescents: an analysis of NHANES 1999-2006. Metabolism. 2012; 61(4): 554-61. 